\title{
NOTE
}

\section{THE CASE CONCERNING UNITED STATES DIPLOMATIC AND CONSULAR STAFF IN TEHRAN}

\author{
Valerie J. Munson*
}

[W]ithout law and without rules, fear reduces all men to a common impotence. ${ }^{1}$

On May 24, 1980, the International Court of Justice ${ }^{2}$ rendered its final judgment in the Case Concerning United States Diplomatic and Consular Staff in Tehran. ${ }^{3}$ By a vote of thirteen to two, the Court decided that the conduct of the Islamic Republic of Iran in the hostage situation had violated and continued to violate obligations owed by it to the United States of America under International Conventions in force between the two countries, as well as under customary rules of general internatonal law. ${ }^{4}$ By unanimous decision, the Court called for the immediate release of members of the United States diplomatic and consular staff and American nationals being held hostage in Iran and ruled that Iran could not keep any member of the United States diplomatic or consular staff for purposes of conducting judicial proceedings or requiring partic-

- Valerie J. Munson is a May, 1982 candidate for the degree of Juris Doctor at Rutgers University School of Law, Camden, where she is an editor of the Rutgers Law Journal.

1. R. Aron, Peace and War 171 (1966).

2. The International Court of Justice (ICJ) was created by the U.N. Charter in 1945 as the primary judicial organ of the United Nations. It is the successor to the Permanent Court of International Justice. The Court is comprised of fifteen judges. The membership of the International Court of Justice at the time the Hostage Case was decided was as follows: President, Sir Humphrey Waldock (United Kingdom); Vice-President Taslim Olauale Elias (Nigeria); and Judges Manfred Lachs (Poland), Isaac Forster (Senegal), Andre Gros (France), Richard R. Baxter (United States of America), P.D. Morozov (Union of Soviet Socialist Republics), Jose Sette Camara (Brazil), Jose Maria Ruda (Argentina), Nagendra Singh (India), Abdullah Ali El-Erian (Egypt), Hermann Mosler (Federal Republic of Germany), Shigeru Oda (Japan), Salah El Dine Tarazi (Syrian Arab Republic) and Robert Ago (Italy). See U.S. Dep't of State, Selected Docs., No. 14, at 2 (1979).

3. U.S. Dep't of State, Selected Docs., No. 17 (1979); Case Concerning United States Diplomatic and Consular Staff in Tehran, [1980] I.C.J. 3.

4. Id. at 21 . 
ipation as a witness in judicial proceedings. ${ }^{5}$ The Court further decided, by a vote of twelve to three, that the Government of the Islamic Republic of Iran was under an obligation to make reparations to the Government of the United States of America for injuries sustained as a result of the hostage situation. ${ }^{6}$

The decision of the International Court of Justice in the Hostage Case stands as an unequivocal reaffirmation of the fundamental principle of diplomatic immunity. ${ }^{7}$ The concept of diplomatic immunity is a well-settled principle of both treaty law and customary international law, ${ }^{8}$ and its maintenance is crucial to international legal order. Without the guarantee of representatives' inviolability, the conduct of diplomacy as we know it would necessarily cease. The Iranian government's failure to observe such a time-honored rule of international law in its handling of the hostage situation is a challenge to diplomatic decorum unparalleled in modern time. ${ }^{9}$

Aside from being a specific example of a government's refusal to honor the principle of diplomatic immunity, the hostage situation in Iran was an incident of international terrorism inimical to world opinion. ${ }^{10}$ Although the term "terrorism" is much more easily invoked than defined," hostage-taking behavior such as that displayed by those seizing the American Embassy in Tehran clearly falls within the general concept of terrorist activity. ${ }^{12}$ One author,

5. Id.

6. Id.

7. See notes 56-58 infra and accompanying text.

8. See notes 56-65 infra and accompanying text.

9. It has been noted that even Hitler did not violate the principle of diplomatic immunity in dealing with his enemies. See Falk, The Iran Hostage Crisis: Easy Answers and Hard Questions, 74 AM. J. INT'L L. 411, 411 (1980).

10. Small and nonaligned countries, as well as major powers, have expressed the view that the seizure of the American Embassy and the taking of hostages was a flagrant violation of international law. The views of some of these nations are reflected in the records of the U.N. Security Council debates during December of 1979. U.N. Doc. S/PV. 2175, (Dec. 1, 1979); U.N. Doc. S/PV. 2176 (Dec. 2, 1979) (excerpts reprinted in U.S. Dep't of State, SELECTED DoCs., No. 16 (1980).

11. See notes 35,37 , and 71 infra and accompanying text.

12. Hostage-taking is among the activities prohibited by numerous international agreements, including articles 3 and 34 of The Geneva Convention Relative to the Protection of Civilian Persons in Time of War, August 12, 1949, 6 U.S.T. 3516, T.I.A.S. 3365, 75 U.N.T.S. 287; The Hague Convention for the Supression of Unlawful Seizure of Aircraft, 22 U.S.T. 1644, T.I.A.S. 7192; The Montreal Convention of 1971 for the Suppression of Unlawful Acts against the Safety of Civil Aviation, 24 U.S.T. 568, T.I.A.S. 7570; The Convention of 1973 on the Prevention and Punishment of Crimes Against Internationally Protected Persons, Including Diplomatic Agents, G.A. Res. 3166, 28 U.N. GAOR, Supp. (No. 30); U.N. Doc. A/9030 (1974); The International Convention Against the Taking of Hostages, 34 U.N. GAOR Supp. (34), U.N. Doc. A/34/819 (1979). 
capturing the key traits of generally accepted definitions of terrorism, ${ }^{13}$ has written that:

Terrorism is a species of coercion utilized to alter the freedom of choice of others. The terroristic process, or terrorism, involves the purposive use of violence or the threat of violence by precipitators against an instrumental target (or victim) in order to communicate to a primary target (another set of targets), a threat of future violence so as to coerce that primary target into behavior or attitudes through intense fear, or intense anxiety, in connection with a demanded power outcome (or in connection with a political motivation). ${ }^{14}$

International terrorism occurs when the conduct in question, its political objective, or both have an international scope. ${ }^{15}$ It can hardly be disputed that those seizing the American Embassy in Tehran used violence or the threat of violence against the embassy staff in order to communicate to the government of the United States the threat of future violence against diplomatic staff now held hostage so as to coerce that government into meeting their demands. ${ }^{16}$ The nature of the premises involved and the status of many of the hostages as diplomatic staff afford the incident "international" classification.

If the hostage situation and its context in international law were diagramed using a scale, the balance weighing in favor of the United States' interests would contain the general principle of diplomatic immunity, the abhorrence on the part of the international community for acts of international terrorism, and a collection of applicable documents embodying the two. ${ }^{17}$ The balance weighing in favor of the Iranian interests, although far from empty, would contain principles of international law which are lacking in both clarity and weight. The principles that would weigh in favor of Iranian interests are those of non-intervention and equity. ${ }^{18}$ Viola-

13. B. Jenkins, International Terrorism: A New Mode of Conflict, 1 (1975); A. Evans \& J. Murphy, Legal aspects of INTERNational Terrorism xv (1978).

14. Paust, An Approach to Decisions with Regard to Terrorism, 7 AKRon L. Rev. 397, 397 (1974).

15. Evans \& MURPhY, at Xv supra note 13.

16. Memorial of the Government of the United States of America, Case Concerning United States Diplomatic and Consular Staff in Tehran. I.C.J. Pleadings 13-28 (1980) [hereinafter cited as Memorial of the United States.]

17. See notes $82-85$ infra and accompanying text.

18. The principle of nonintervention has not been as clearly enunciated or as extensively codified as the principle of diplomatic immunity, nor has it been as forcefully or publicly lauded as the many conventions aimed at counteracting terrorist activity. Nevertheless, it is a well-settled rule of international law and one which the United Nations has recog- 
tions by the United States of the principle of non-intervention as regards the internal affairs of Iran, it is argued, are the true cause of the present hostage situation, and the principle of equity should operate to allow the assessment of the historical context in resolving the dispute. ${ }^{19}$

In its decision of the Case Concerning United States Diplomatic and Consular Staff in Tehran, the International Court of Justice reaffirmed those principles weighing in favor of the United States. Yet, in looking to the future, it is difficult to see how similar tragedies can be prevented without a fundamental understanding of the causes involved and a questioning of why those principles of international law which weighed in favor of Iranian interests in the hostage situation are so lacking in clarity and enforceability. The object of attempting to understand, the object of questioning, is not to condone either the causes of terrorism or its results.

This Note will explore the problem of international terrorism and the responses that it has produced from the international community. It will then focus on the Iranian hostage situation, the arguments made by the United States Government, and the views expressed by the Government of the Islamic Republic of Iran. Next, it will consider the dissenting opinion of Judge Tarazi and his contention that the events of November 4, 1979, should not be divorced from the larger context of Iranian-American relations. Finally, it will briefly examine the principle of non-intervention as reflected in United Nations documents. This approach to the events in Iran and the decision of the International Court of Justice will, it is hoped, afford a perspective conducive to the search for realistic means of preventing similar incidents of international terrorism. ${ }^{20}$

nized. The principle of nonintervention dictates that States respect one another's right to conduct domestic affairs free of foreign pressure or interference, that upholding the principle of nonintervention is crucial to the maintenance of international order. See VINCENT, note 124 infra.

19. Id. It has been strongly suggested that the Shah's return to power in Iran in 1953 was the direct result of a coup orchestrated by the CIA. See R. Cottam, Nationalism in Iran 332 (2d rev. ed. 1979). See generally K. Roosevelt, Countercoup: The Struggle FOR THE CONTROL OF IRAN (1979). It has also been suggested that once the Shah returned to power, his position and authority were in large part dependent upon United States involvement in Iran. See note 120 infra.

20. There are many interesting and important questions arising out of The Case Concerning United States Diplomatic and Consular Staff in Tehran which of necessity fall outside the scope of this Note. One of the most interesting involves the effectiveness of ICJ judgments. For a helpful background on the methods of securing compliance with interna- 


\section{Responses To The Problem Of International TERRORISM}

\section{A. League of Nations}

The problem of international terrorism thrust itself to the forefront of public concern in 1934 with the assassination of the Austrian Chancellor Engelbert Dollfus ${ }^{21}$ and the murders of King Alexander of Yugoslavia ${ }^{22}$ and French Foreign Minister Louis Barthou in Marseilles. ${ }^{23}$ As a result of the terrorist attack on its Foreign Minister and the refusal of the Italian government to extradite the two Croations believed responsible for the attack, the French government requested that the Council of the League of Nations address the question of political terrorism. The Council created a committee of experts and assigned them the task of drafting an international convention on the repression of terrorism. In 1937 the League's international conference on the repression of terrorism convened at Geneva and adopted two conventions. ${ }^{24}$ The first, the Convention for the Prevention and Punishment of Terrorism, ${ }^{25}$ established certain terrorist activities as criminal offenses for which extradition would be granted. ${ }^{26}$ It was signed by twenty-four states but ratified by only one, India. The second convention created an International Criminal Court and granted that court jurisdiction over terrorist crimes. ${ }^{27}$ It was signed by only eleven states and ratified by none. Having failed to receive a sufficient number of ratifications, neither convention entered into force. ${ }^{28}$ Despite

tional decisions and awards, see W. Jenks, The Prospects of International AdjudicaTION 663-724 (1964).

21. R. Friedlander, Terrorism 87 (1979).

22. Id.

23. Id.

24. International Terrorism: National, Regional, and Global Perspectives 323 (P. Alexander ed. 1976).

25. 19 League of Nations O.J. 23 (1938).

26. Acts designated criminal offenses under the terms of the Convention include wilful acts causing death or grievous bodily harm to Heads of State, the spouses of Heads of State, or other persons charged with public functions when the act is directed against them in their public capacity; wilful destruction of, or damage to, the public property of another High Contracting Party; wilful acts calculated to endanger the lives of members of the public; an attempt to commit any of the enumerated offenses; and the manufacture, obtaining, possession, or supplying of arms with a view to the commission in any country of the enumerated offenses. Id.

27. Id. at 37.

28. Parties may not be bound to an international agreement without their express consent. Art. 14 of the Vienna Convention in the Law of Treaties, a treaty codifying customary law concerning the law of treaties, provides that: 
these difficulties, the League's efforts established a precedent for international attempts to control terrorism.

\section{B. United Nations}

1. Ad Hoc Committee on International Terrorism. The United Nations did not take direct notice of the problem of international terrorism until 1972. By that time incidents of terrorist acts against international civil aviation, diplomatic personnel, and unarmed civilians were becoming more and more a matter of public concern. ${ }^{29}$ The massacre of eleven Israeli athletes at the hands of terrorists during the 1972 Olympics in Munich and the ensuing outrage on the part of private citizens and governments alike demanded response by the international community.

Secretary-General Kurt Waldheim requested that the issue of terrorism be included on the agenda of the General Assembly on September 8, 1972..$^{30}$ As originally proposed by him, the question was to have been considered by the United Nations under the title: "Measures to prevent terrorism and other forms of violence which endanger or take innocent human lives or jeopardize fundamental freedom." 31 However, in response to a suggestion by the Ambassador of Saudia Arabia, the title was amended by the General Assembly to include the phrase: "and study of the underlying cause of those forms of terrorism and acts of violence which result in misery, frustration, grievance and despair and which cause some people to

1. The consent of a State to be bound by a treaty is expressed by ratification when:

a. the treaty provides for such consent to be expressed by means of ratification,

b. it is otherwise established that the negotiating States were agreed that ratification should be required,

c. the representative of the State has signed the treaty subject to ratification, or

d. the intention of the State to sign the treaty subject to ratification appears from the full powers of its representatives or was impressed during the negotiation.

2. The consent of a state to be bound by a treaty is expressed by acceptance or approval under conditions similar to those which apply to ratification.

Vienna Convention on the Law of Treaties opened for signature, May 23, 1969, U.N. Doc. A/CONF. 39/27, art. 4; as cited in 63 AM. J. INT'L L. 875 (1969).

29. Hannay, International Terrorism: The Need for a Fresh Perspective, 8 INT'L LAW 268, 268-70 (1973).

30. 27 U.N.GAOR, Supp. (No. 30) 3 (1972). "The Secretary-General considers that the current trend towards terrorism and senseless violence is so alarming and has such grave implications that it should be considered by the General Assembly, with the hope that agreed measures can be found which will help to reverse this trend and prevent such tragedies in the future."

31. Id. at 1. 
sacrifice human lives, including their own, in an attempt to effect radical change." ${ }^{32}$ The amendment reflected the disagreements that had traditionally hampered the international legal community in responding to terrorism and which were to once again surface in the United Nations' consideration of the matter.

The President of the U.N. General Assembly appointed a thirty-five member state Ad Hoc Committee on International Terrorism which met from July 23 to August $11,1973 .{ }^{33}$ The Committee failed to come to an agreement on certain fundamental issues and the session ended in an impasse. Chief among the disagreements between the members were those concerning the definition of international terrorism and the legitimacy of political violence by organized groups. ${ }^{34}$

The terms "terror" and "terrorism" do not have a widely-accepted meaning in law, nor do they refer to a well-defined and readily-identified set of factual events. ${ }^{35}$ The United States and a minority of other states contended that terrorist acts could be separated, both logically and legally, from the social or political motivations behind them. ${ }^{36}$ Third World and Soviet block members, on the other hand, sought to exempt self-determination movements and liberation struggles from prohibitions against terrorism. ${ }^{37}$ The end result was an assortment of conflicting draft proposals and heated debates.

32. U.N. Doc. A/PV2037, item 92 (1972).

33. G.A. Res. 3034, 27 U.N. GAOR, Supp. (No. 30) 119, U.N. Doc. A/8730 (1972).

34. U.N. General Assembly Report of the Ad Hoc Committee on Terrorism: 28 U.N. GAOR, Supp. (No. 28), U.N. Doc. A/9028 (1973).

35. Mallison \& Mallison, The Concept of Public Purpose Terror in International Law, 18 How. L.J. 12, 12 (1973). Despite the schism that divides those who focus on the specific acts of violence in defining terrorism and those who would place more emphasis on motive, at least one author has suggested that a common pattern emerges suggesting that terrorism is "fear created by force and intimidation having a purposefully harmful objective." See also 1 R. Friedlander, Terrorism 4 (1979).

36. Compilation of Relevant Views Expressed in the Course of the General Debate at the General Assembly, U.N. Doc. A/C. 6/L.867 (1972).

37. Id. See also Hoveyda, The Problem of International Terrorism at the United Nations, in FrIEDlander, supra note 35, at 71. The terms "self-determination movement," "liberation struggle," "war of national liberation" and the like are generally used to denote violent activity connected with the implementation of the Communist doctrine of internal war. They are generally used by Soviet jurists to justify war in three sets of circumstances: to defend a homeland, to liberate a people from capitalism, and to liberate a colony from colonial power: Firmage, The "War of National Liberation" and the THIRD World, LAW AND CIVIL WAR IN THE MODERN WORLD 309 (1974). In the context of intermational control of terrorism, the terms are used primarily to denote the struggle of those under colonial domination. Compilation of Relevant Views Expressed in the Course of the General Assembly, U.N. Doc. A/C. 6/L. 867 (1972). 
The Ad Hoc Committee began its efforts anew in $1977 .^{38}$ Public opinion was high in the wake of the Entebbe incident and the Western states, in particular, were growing increasingly concerned as the number of aerial highjackings increased. Again, the Committee reached an impasse due to conflicting views on the definition of terrorism and the legitimacy of politically-motivated terrorist behavior. ${ }^{39}$

Yet a third session was held from March 19 to April 6, 1979. This time, after much debate, the Ad Hoc Committee adopted a report for the regular 1979 meeting of the General Assembly. ${ }^{40}$ The report recommended that the General Assembly take specific steps to condemn acts of international terrorism and to promote cooperation among member-states in combating terrorist activity. ${ }^{41}$ In addition, it urged the Assembly to take note of the study of the underlying causes of international terrorism contained in the report and to pay special attention to all situations that might give rise to international terrorism and endanger international security. ${ }^{42}$ Among those phenomena suggested in the report to be underlying causes of international terrorism were colonialism, racism, policies of expansionism, and interference in the internal affairs of other States. ${ }^{43}$ The Committee's report did not suggest that a "just cause" could either justify or legitimize acts of terrorism. However, the Committee did recommend that the General Assembly concern itself with the elimination of the causes of terrorism as part of an overall approach to combating the problem. ${ }^{44}$

By urging the study of the underlying causes of terrorist be-

38. This second implementing resolution has the same title as the first and was passed on December 15, 1976. G.A. Res. 31/102, 31 U.N. GAOR, Supp. (No. 39) 185, U.N. Doc. A/31/39 (1976).

39. U.N. General Assembly: Report of the Ad Hoc Committee on International Terrorism, 32 U.N. GAOR, Supp. (No. 37), U.N. Doc. 2/32/37 (1977).

40. U.N. General Assembly: Report of the Ad Hoc Committee on International Terrorism, 34 U.N. GAOR, Supp. (No. 37), U.N. Doc. A/34/37 (1979).

41. Id. at 32-33. The Committee recommended, among other things, that the General Assembly should unequivocally condemn all acts of international terrorism which endanger or take human lives or jeopardize fundamental freedoms, take note of the Committee's study of the causes of terrorism, pay special attention to situations that may give rise to international terrorism and urge states to cooperate in all ways possible to prevent and combat international terrorism.

42. Id.

43. Id. at 20-21 (working paper submitted by Algeria, Barbados, India, Iran, Nigeria, Panama, the Syrian Arab Republic, Tunisia, Venezuela, Yugoslavia, Zaire and Zambia, A/AC. $160 /$ W6/R1).

44. U.N. General Assembly: Report of the Ad Hoc Committee on International Terrorism, supra note 40 , at $33-34$. 
havior, the Committee's final report reflected the concern of third world and Soviet block members that politically-motivated terrorist behavior be accorded special attention, if not special status. At the same time, the Committee's recommendation of an unequivocal condemnation of all acts of international terrorism reflected the United States' position that terrorist behavior should be dealt with uniformly under international law.

2. United Nations Convention Against the Taking of Hostages. On January 21, 1977, the General Assembly of the United Nations adopted a resolution creating a new Ad Hoc Committee of thirtyfive member states to draft an international convention against the taking of hostages. ${ }^{45}$ The work of this committee took on special import in light of the failure of the U.N. Ad Hoc Committee on International Terrorism to draft a comprehensive treaty to control international terrorism. There was a universal consensus that the taking of hostages is a reprehensible act violative of human rights principles recognized in the Universal Declaration of Human Rights $^{46}$ and the International Covenant on Civil and Political Rights. ${ }^{47}$ There was, however, no general prohibition against the taking of hostages in time of peace under traditional international law.

The first two sessions of the Ad Hoc Committee in 1977 and 1978 were marked by fundamental differences of opinion on basic issues. ${ }^{48}$ These issues paralleled, to some extent, those addressed by the Ad Hoc Committee on International Terrorism, and included disagreements on the scope of the convention, the convention's application to the activities of national liberation groups, the definition of the taking of hostages, extradition and the right of asylum, and adherence to the principles of sovereignty and territorial integrity in the context of the release of hostages. ${ }^{49}$

At its third session, which concluded on February 16, 1979, the Ad Hoc Committee resolved the majority of its differences and drafted an International Convention Against the Taking of Hos-

45. G.A. Res. 103, 31 U.N. GAOR, U.N. Doc. 2/31/430 (Jan. 1977).

46. G.A. Res. 217 A, U.N. Doc. A/810 (1948).

47. G.A. Res. 2200A, 21 U.N. GAOR, Supp. (No. 16) 52, U.N. Doc. A/6316 (1966).

48. Report of the Ad Hoc Committee on the Drafting of an International Convention Against the Taking of Hostages, 32 U.N. GAOR, Supp. (No. 39), U.N. Doc. A/32/39 (1977); see also Report of the Ad Hoc Committee on the Drafting of an International Convention Against the Taking of Hostages, 33 U.N. GAOR, Supp. (No. 39), U.N. Doc. A/33/39 (1978).

49. Id. 
tages. ${ }^{50}$ The Convention directs those states party to it to proscribe the organization, instigation, encouragement, or participation in hostage-taking; ${ }^{51}$ to take all possible measures to secure the release of hostages held within their territorial boundaries; ${ }^{.2}$ to observe the principle of extradite or prosecute; ${ }^{53}$ and to punish appropriately those who take hostages. ${ }^{54}$ Revealingly, the Convention specifically exempts hostage-taking committed in the course of national liberation conflicts ". . . in which peoples are fighting against colonial domination and alien occupation and against racist regimes in the exercise of their right of self-determination. ..."ss Once again, a compromise was reached. Certain specific behavior, hostage-taking, was isolated and proscribed. Yet, such behavior occurring in connection with a particular type of self-determination conflict was exempted.

3. Protection of Diplomatic Personnel. Diplomatic agents have been accorded special privileges and immunities since the days of the Greeks and Romans. ${ }^{56}$ Based, no doubt, in pure necessity, the inviolability of diplomatic agents is one of the earliest fundamental principles of customary international law. ${ }^{57}$ If diplomatic interchange is to be at all effective, the security of diplomatic agents must be safeguarded. ${ }^{58}$

When the International Law Commission met for the first time in 1949, it listed the topic of "diplomatic intercourse and immunities" among the fourteen topics deemed suitable for codification. ${ }^{59}$ The United Nations General Assembly requested that the Commission give priority to the topic, ${ }^{60}$ and, in 1958, the Commission adopted forty-five draft articles and recommended that they form

50. International Convention Against the Taking of Hostages, note 12, supra.

51. Id. art. 4 , at 6 .

52. Id. art. 3 , at 6 .

53. Id art. 8, at 8. According to this principle, a State must either punish a fugitive criminal itself or surrender him to the State in which the crime was committed. See generally C. FENWICK, INTERNATIONAL LAW 388-89 (4th ed. 1965).

54. International Convention Against the Taking of Hostages, supra note 12, art. 2, at 6.

55. Id. art. 12, at 10.

56. FENWICK, supra note 53, at 561.

57. Id

58. For an overview of measures taken to assure the safety of diplomats from the time of Greece and Rome until the establishment of the International Law Commission, see Note, Terrorist Kidnapping, 5 CORNELl INT'L L.J. 189, 190-92 (1972).

59. Summary Records of the First Session of the International Law Commission April 12-June 9, 1949, [1949] Y.B. INT'L L. COMM'N, 49.

60. G.A. Res. 685, 7 U.N. GAOR, Supp., (No. 312) U.N. Doc. A/Res/19 (1952). 
the basis for a multilateral convention. ${ }^{61}$ After studying the Commission's report and recommendation, the General Assembly convened the United Nations Conference on Diplomatic Intercourse and Immunities, which met in Vienna in 1961. Out of that conference came the Vienna Convention on Diplomatic Relations, a multilateral agreement codifying the law with regard to the status of diplomats and members of their staffs. ${ }^{62}$

The principle of the personal inviolability of diplomats is set forth in Article 29 of the Vienna Convention as follows: "The person of a diplomatic agent shall be inviolable. He shall not be liable to any form of arrest or detention. The receiving state shall treat him with due respect and shall take appropriate steps to prevent any attack on his person, freedom or dignity." Related provisions concerning the inviolability of mission premises and property are set forth in Article 22 and Article $24 .{ }^{63}$

The International Law Commission also submitted draft articles to the General Assembly concerning the privileges and immunities of consular staff parallelling to a great extent those pertaining to diplomatic personnel. A second conference, the United Nations Conference on Consular Relations, met in 1963 and on April 22 of that year adopted the Vienna Convention on Consular Relations based on the Commission's draft. ${ }^{64}$ Just as its predecessor convention did in the case of diplomats, the Vienna Convention on Consular Relations embodied the principle of inviolability of consular officers. Article 40 reads: "The receiving state shall treat consular officers with due respect and shall take all appropriate steps to prevent any attack on their person, freedom or dignity." Related pro-

61. Report of the International Law Commission Covering the Work of its Tenth Session April 28-July 4, 1958, [1958] Y.B. INT'L L. COMM'N 49.

62. Vienna Convention on Diplomatic Relations, April 15, 1961, 23 U.S.T. 2230, T.I.A.S. No. 7502,500 U.N.T.S. 96.

63. Id. at 106. Article 22 reads:

1. The premises of the missions shall be inviolable. The agents of the receiving State may not enter them, except with the consent of the head of the mission.

2. The receiving State is under a special duty to take all appropriate steps to protect the premises of the missions against any intrusion or damage and to prevent any disturbance of the peace of the mission or impairment of its dignity.

3. The premises of the missions, their furnishings and other property thereon and the means of transport of the missions shall be immune from search, requisition, attachment or execution.

Article 24 reads:

The archives and documents of the mission shall be inviolable at any time and wherever they may be.

64. Vienna Convention on Consular Relations, April 15, 1963, 21 U.S.T. 77, T.I.A.S. No. 6820 , 596 U.N.T.S. 261. 
visions concerning the inviolability of consular premises and property are set forth in Article 31 and Article $33 .{ }^{65}$

Although the status of diplomatic and consular personnel was well established in customary international law and cogently restated in the Vienna Convention, the international community became increasingly concerned about the safety of such persons in the face of escalating terrorist threats. On December 14, 1973, the General Assembly of the United Nations adopted the Convention on the Prevention and Punishment of Crimes Against Internationally Protected Persons, Including Diplomatic Agents. ${ }^{66}$ The term "internationally protected person" is unique to this Convention and is defined in the document itself in a manner encompassing those international figures most frequently the target of terrorist activity. ${ }^{67}$ The Convention provides that persons who have allegedly committed certain crimes against diplomatic agents and other pro-

65. Id. at 288. Article 31 reads:

1. Consular premises shall be inviolable to the extent provided in this Article.

2. . The authorities of the receiving State shall not enter the part of the consular premises which is used exclusively for the purpose of the work of the consular post except with the consent of the head of the consular post or his designee or of the head of the diplomatic mission of the sending State. The consent of the head of the consular post may, however, be assumed in case of fire or other disaster requiring prompt protective action.

3. Subject to the provisions of paragraph 2 of this Article, the receiving State is under a special duty to take all appropriate steps to protect the consular premises against any intrusion or damage and to prevent any disturbance of the peace of the consular post or impairment of its dignity.

4. The consular premises, their furnishings, the property of the consular post and its means of transport shall be immune from any form of requisition for purposes of national defense or public utility. If expropriation is necessary for .such purposes, all possible steps shall be taken to avoid impeding the performance of consular functions, and prompt, adequate and effective compensation shall be paid to the sending State.

Article 33 reads:

The consular archives and documents shall be inviolable at all times and wherever they may be.

66. See note 12 supra.

67. The definition of "internationally protected person" is defined in Article 1(1) of the Convention as follows:

[I]nternationally protected person means:

(a) a Head of State, including any member of a collegial body performing the functions of a Head of State under the constitution of the State concerned, a Head of Government or a Minister for Foreign Affairs, whenever any such person is a foreign state, as well as members of his family who accompany him;

(b) any representative or official of a State or any official or other agent of an international organization of an intergovernmental character who, at the time when and in the place where a crime against him, his official premises, his private accomodation or his means of transport is committed, is entitled pursuant to international law to special protection from any attack on his person, freedom or dignity, as well as members of the family forming part of his household. . . . 
tected persons ${ }^{68}$ should either be extradited or prosecuted by the state within whose territory they are found. In addition, the Convention contains provisions concerning cooperation, the exchange of information, and the treatment to be accorded alleged offenders. ${ }^{69}$

As was the case with the Vienna Convention, this Convention was based on draft articles prepared by the International Law Commission in $1972 .^{70}$ A problem arose during the discussion of those articles concerning the applicability of the Convention to peoples struggling against colonialism, foreign occupation, racial discrimination, and apartheid. ${ }^{71}$ Those who spoke in favor of a provision exempting such situations from the scope of the Convention did not suggest that motive would excuse the commission of those crimes covered by the Convention. Instead, they expressed the fear that absent a specific exemption, the Convention might be used as a means of suppressing the right of peoples to self-determination and independence. ${ }^{72}$ An exempting provision of the type proposed was unacceptable to many delegations, and the divergent views on the issue threatened to create an impasse. However, a compromise was reached and a paragraph was included in the General Assembly Resolution to which the Convention is annexed, noting that:

the provisions of the Convention cannot in any way prejudice the exercise of the legitimate right to self-determination and independence. . . . ${ }^{73}$

68. Those crimes include murder, kidnapping or other attacks upon the person or liberty of a protected person, as well as any threat or attempt to commit any such attack or complicity in any such attack. See International Convention Against the Taking of Hostages, note 12 supra, art. 2.

69. See generally, Wood, The Convention on the Prevention and Punishment of Crimes Against Internationally Protected Persons, Including Diplomatic Agents, 23 INT'L CoMP. L. Q. 791 (1974).

70. Report of the International Law Commission on the Work of its Twenty-Fourth Session, 27 U.N. GAOR Supp. (No. 10), U.N. Doc. A18710/Rev. 1 (1972).

71. A new article, submitted by the delegations of 37 nations, read: "No provision of the present articles shall be applicable to peoples struggling against colonialism, alien domination, foreign occupation, racial discrimination and apartheid in the exercise of their legitimate rights to self-determination and independence." U.N. Doc. A/C.6/L.951/Rev. 1.

72. U.N. Doc. A/C.6/SR.1439, at 4-10 (1973). (1974).

73. G.A. Res. 316628 U.N. GAOR. (2202 plen. mtg.) 499 U.N. Doc. A/RES/3166 


\section{The Iranian Hostage Situation And The INTERNATIONAL COURT OF Justice}

On November 29, 1979, the United States instigated proceedings in the International Court of Justice against Iran in a case arising out of the seizure of the United States Embassy in Tehran and United States Consulates in Tabriz and Shiraz, and the taking and detention of hostages of two private United States citizens and the United States diplomatic and consular staff in Tehran. ${ }^{74}$ Pursuant to the United States' request for the indication of provisional measures, ${ }^{75}$ the Court, by a unanimous order, determined that, pending final judgment, Iran should immediately return the Embassy premises to the control of the United States Government and release the United States nationals and allow them to leave Iran. ${ }^{76}$

The United States subsequently filed a memorial with the Court $^{77}$ and participated in public hearings held March 18-20, 1980. It averred that on November 4, 1979, the United States Embassy in Tehran and the United States Consulates in Tabriz and Shiraz were overrun by demonstrators ${ }^{78}$ and that the attackers took as hostage all diplomatic and consular staff, as well as a private United States citizen in the Embassy compound at the time of the seizure. $^{79}$ The United States further alleged that at the time of the seizure of the Embassy the Iranian Government failed, despite repeated requests for help, to provide relief and protection to the Embassy and its staff or to attempt to persuade the demonstrators to cease their actions against the Embassy. ${ }^{80}$ The United States alleged that the demonstrators occupying the Embassy compound had ransacked embassy and consulate archives and documents and subjected the hostages to severe discomfort, isolation, and threats of

74. U.S. Dep'T of State, Selected Docs. No. 14(1) (1979).

75. The United States submitted its case against Iran to the International Court of Justice on November 29, 1979, and requested interim measures of protection under Article 41 of the Court's statute, which provides that:

The Court shall have the power to indicate, if it considers that the circumstances so require, any provisional measures which ought to be taken to preserve the respective rights of either party.

76. U.S. Dep't of State, Selected Docs. No. 15, at 15 (1979); Case Concerning United States Diplomatic and Consular Staff in Tehran, supra note 3, at 7.

77. Memorial of the United States supra note 16.

78. Id. at 13-14.

79. In addition to the hostages held at the Embassy, the United States Charge d'Affaires and two other diplomats were confined to the premises of the Iranian Ministry of Foreign Affairs. Id. at $18-22$.

80. Id. at $15-18$. 
criminal prosecution and death. ${ }^{81}$ The United States argued that the Islamic Republic of Iran, through acts of omission and commission, had violated its international legal obligations to the United States under customary international law and under the Vienna Convention on Diplomatic Relations, ${ }^{82}$ the Vienna Convention on Consular Relations, ${ }^{83}$ the Convention on the Prevention and Punishment of Crimes Against Internationally Protected Persons Including Diplomatic Agents, ${ }^{84}$ and the Treaty of Amity, Economic Relations, and Consular Rights between the United States and Iran. ${ }^{85}$ The United States contended that the Iranian Government was responsible for its acts of omission in failing to take appopriate steps to protect United States nationals and diplomatic and consular premises from attack and its additional failure to enforce the right of free communication, to facilitate departure of official personnel, to cooperate in prevention of the continuing crimes being committed at the Embassy, or to apprehend the perpetrators of such crime and submit them to the proper authorities for prosecution. ${ }^{86}$ The United States further argued that the Iranian Government was responsible for acts of commission as well in that "from and after a point in time shortly after the attack and seizure, if not before, the 'students' have in fact been acting on behalf of the Government of Iran."87

The United States requested the Court to declare that the Iranian Government had violated its international legal obligations to the United States and that Iran must: release the hostages, accord the United States diplomatic and consular personnel the protection and immunities to which they were entitled (including immunity from criminal jurisdiction), provide the diplomatic and consular personnel with the facilities to leave Iran, submit those responsible for the crimes committed to prosecution in Iran or extradite them to the United States, and pay the United States repara-

81. Id. at $18-24$.

82. Vienna Convention on Diplomatic Relations, April 15, 1961, 23 U.S.T. 3230, T.I.A.S. No. 7502, 500 U.N.T.S. 96. See notes $62-63$, supra, and accompanying text.

83. Vienna Convention on Consular Relations, supra note 62. See also notes 63-65 supra and accompanying text.

84. Convention on the Prevention and Punishment of Crimes Against Internationally Protected Persons, Including Diplomatic Agents, December 14, 1973, 28 U.S.T. 1977, T.I.A.S. No. 8532. See notes 66-73 and accompanying text.

85. Treaty of Amity, Economic Relations, and Consular Rights Between the United States and Iran, August 15, 1975, 8 U.S.T. 899, T.I.A.S. No. 3853, 384 U.N.T.S. 93.

86. Memorial of the United States, supra note 16, at 45.

87. Id. at 46. 
tion. $^{88}$

The Islamic Republic of Iran took no part in the proceedings before the International Court of Justice. Its position was, however, set forth in two letters addressed to the Court by its Minister for Foreign Affairs on December 9, 1979 and March 16, 1980. ${ }^{89}$ In its letter of December 9,1979, sent to the Court at the time of its hearing on the interim measures requested by the United States, the Government of Iran raised two fundamental objections to the Court's proceedings. First, it argued that the examination of the "numerous repercussions" of the recent revolution in Iran was a matter solely within the national sovereignty of Iran. Secondly, it maintained that the Court could not and should not take cognizance of the case because the question before it "only represents a marginal and secondary aspect of an overall problem, one such that it cannot be studied separately, and which involves, inter alia, more than 25 years of continual interference by the United States in the internal affairs of Iran. . . ."90 The Government of Iran repeated its views, without change, in its communication of March 16, $1980 . .^{91}$

The Court exercised jurisdiction based on the Optional Protocols to the two Vienna Conventions of 1961 and 1963 concerning diplomatic and consular relations, ${ }^{92}$ and the 1955 Treaty of Amity, Economic Relations, and Consular Rights between the United States and Iran. ${ }^{93}$ The Court did not address the question of whether the fourth document cited by the United States, the Convention on the Prevention and Punishment of Crimes Against Internationally Protected Persons Including Diplomatic Agents, ${ }^{94}$ provided a basis for the exercise of its jurisdiction.

The Court did take note of the considerations put forth by the Iranian Government in its letter to the Court. ${ }^{95}$ However, reiterat-

88. Id. at 77-80. See also U.S. Dep't of StAte, Selected Docs., No. 16, at 20 (1980).

89. See U.S. Dep't of State, Selected Docs., No. 17, at 11 (1980).

90. U.S. DeP'T of State, Selected Docs., supra note 3, at 11.

91. Letter to the International Court of Justice from the Minister for Foreign Affairs of Iran dated 16 March 1980, reprinted in U.S. DEP'T OF STATE, supra note 3, at 6-7.

92. Optional Protocol Concerning the Compulsory Settlement of Disputes accompanying the Vienna Convention on Diplomatic Relations, supra note 62, art. 1; Optional Protocol Concerning the Compulsory Settlement of Disputes accompanying the Vienna Convention on Consular Relations, supra note 64, art. 1.

93. Treaty of Amity, Economic Relations, and Consular Rights Between the United States and Iran, supra note 85, art. xxi, para. 2.

94. U.S. Dep't of State, Selected Docs., No. 17, supra note 3, at 2.

95. Id. at 13. 
ing its findings at the time of the hearing on interim measures, the Court found that the hostage situation could not be viewed as "secondary" or "marginal" in light of the fundamental nature of the legal principles involved and that no provision of its statutes or rules suggested that the Court should decline to take cognizance of one aspect of a dispute between states simply because other aspects of that dispute were not before it. ${ }^{96}$

In considering the merits of the case before it the Court had to make two central determinations. First, it had to decide whether the acts in question were imputable to the Iranian State. Second it had to determine whether those acts were incompatible with Iranian obligations under treaties in force or general principles of international law. ${ }^{97}$ For purposes of analysis the Court divided the events under consideration into two phases. The first phase covered "the armed attack on the United States Embassy by militants on 4 November 1979, the overrunning of its premises, the seizure of its inmates as hostages, the appropriation of its property and archives and the conduct of the Iranian authorities in the face of those occurrences," 98 and also included the attacks on the United States Consulates at Tabriz and Shiraz. ${ }^{99}$ The second phase consisted of "the whole series of facts which occurred following the completion of the occupation of the United States Embassy by the militants, and the seizure of the Consulates at Tabriz and Shiraz." 100

Regarding the first phase, the Court found that the facts did not establish that the militants acted on behalf of the Iranian State. They did not have any official status as "agents" of the state, nor had they been charged by a competent organ of the Iranian State to perform a specific operation. ${ }^{101}$ Therefore, their conduct could not be directly imputed to the Iranian State. However, the Court's finding in that regard did not absolve Iran of all responsibility in connection with events during the first phase. The Court determined that the Iranian State did have an obligation under both customary international law and the Vienna Conventions of 1961 and 1963 to take appropriate steps to ensure the protection of the United States Embassy and Consulates, their personnel, and their

\footnotetext{
96. Id. at 15 .

97. Id. at 15.

98. Id

99. Id.

100. Id. at 17.

101. Id. at 15
} 
archives. ${ }^{102}$ The total lack of response on the part of Iranian authorities during the period, despite urgent and repeated requests for aid was, the Court found, due to "more than mere negligence or lack of appropriate means." 103 It held that the failure of the Iranian Government to take steps to prevent the militants' invasion of the Embassy and Consulates or to persuade them to withdraw once the invasions had taken place constituted a clear and serious violation of general principles of international law, the Vienna Conventions of 1961 and 1963, and the 1955 Treaty of Amity, Economic Relations, and Consular Rights. ${ }^{104}$

Concerning the second phase of the events before it, the Court found that once the embassy and consular premises had been occupied and diplomatic and consular personnel taken hostage, the Iranian State had an obligation under the Vienna Conventions and general international law to restore those premises to United States control and offer reparation for the damages. ${ }^{105}$ It further found that the announced policy of the Ayatollah Khomeini and other organs of the State to maintain the occupation of the Embassy and the detention of diplomatic and consular staff as hostages transformed those acts into acts of the Iranian State. ${ }^{106}$ The Court held that:

The Iranian authorities' decision to continue the subjection of the premises of the United States Embassy to occupation by militants and of the Embassy staff to detention as hostages, clearly gave rise to repeated and multiple breaches of the applicable provisions of the Vienna Conventions even more serious than those which arose from their failure to take any steps to prevent the attacks on the inviolability of these premises and staff. ${ }^{107}$

In sum, the Court decided that Iran had violated and continued to violate obligations owed by it to the United States under

102. Id. at 16 .

103. Id.

104. Id.

105. Id. In brief, the Court found that the Iranian State had an obligation under the Vienna Convention of 1961 to protect the Embassy premises, archives, and personnel and to afford diplomatic staff freedom of movement and communication; that analogous obligations existed in regard to consular premises, archives and staff under the Vienna Convention of 1963; and that Iran had an obligation to afford private citizens protection and security under the 1955 Treaty of Amity, Economic Relations, and Consular Rights. It also found parallel obligations arising under general international law.

106. Id at 17.

107. Id. 
both international conventions and customary international law; ${ }^{108}$ that Iran must take immediate steps to redress the situation by releasing the United States Charge d'Affaires, diplomatic and consular staff and other United States nationals held hostage, and facilitate their departure from Iran; ${ }^{109}$ that no member of the diplomatic or consular staff could be kept in Iran for purposes of judicial proceedings whether as a witness or a defendant; 110 that Iran must make reparations to the United States; ${ }^{111}$ and that the form and amount of such reparation, ${ }^{12}$ failing agreement between the parties, shall be settled by the Court. ${ }^{113}$

\section{The Views Of Judge Tarazi And The Issue Of AMERICAN INTERVENTION IN THE INTERNAL AFFAIRS OF IRAN}

Although he concurred with the majority's finding that the Government of Iran should comply with its obligations under the Vienna Convention on Diplomatic Relations and the Vienna Convention on Consular Relations, Judge Tarazi disagreed with the majority's decision not to consider the question of possible United States responsibility vis-a-vis the Government of Iran. In his dissenting opinion, Tarazi maintained that the Court could have and should have complied with the views set forth in the Iranian Gov-

108. Id. at 21 . The vote on this issue was thirteen to two.

The Court held that the failure of the Iranian Government to take appropriate steps to protect the premises of the United States Embassy and its diplomatic and consular staff from any attack and from any infringement of their inviolability, and to ensure the security of such other persons as might be present on those premises constituted violations of Iran's obligations to the United States under the provisions of: Article 22, paragraph 2, and Articles 24, 25, 26, 27 and 29 of the 1961 Vienna Convention on Diplomatic Relations; Articles 5 and 36 of the 1963 Vienna Convention on Consular Relations; Article II, paragraph 4, of the 1955 Treaty of Amity, Economic Relations, and Consular Rights. Id. at 16.

It further held that the Iranian government's failure, once the seizure had taken place, to take every appropriate step to bring the infringements of the inviolability of the premises, archives and diplomatic and consular staff to an end, to restore the Consulates at Tabriz and Shiraz to United States control, to establish generally the status quo and offer reparation for damage constituted additional violations of: Articles 22, 25, 26, 27 and 29 of the 1961 Vienna Convention on Diplomatic Relations; Article 33 of the 1963 Vienna Convention on Consular Relations; and Article II, paragraph 4, of the 1955 Treaty of Amity, Economic Relations, and Consular Rights. Id. at 18.

109. Id. at 21 . The vote on this issue was unanimous.

110. Id. The vote on this issue was unanimous.

111. Id. The vote on this issue was twelve to three.

112. The Court held that since Iran's breaches of its obligation were continuing at the time judgment in the case was rendered, the form and amount of reparation could not be determined. $I d$. at 20.

113. Id. at 21 . The vote on this issue was fourteen to one. 
ernment's letters and studied the historical facts preceding the seizure of the United States Embassy. ${ }^{114}$ He suggested that the responsibilty incurred by Iran in the hostage situation was properly viewed as relative to that of the United States, not absolute, and should have been qualified as such in the Court's judgment. ${ }^{115}$

It is not clear from Judge Tarazi's dissent whether he advocates an apportionment of wrong similar to that done in accordance with the "comparative fault" doctrine in the American law of torts, ${ }^{16}$ or whether he is simply suggesting that the International Court of Justice should take cognizance of the historical context in which a case arises and enunciate that context in its written opinions. ${ }^{117}$

The implementation of a "comparative fault" type of doctrine by the International Court of Justice would be no small feat. Not only would it necessitate the Court's engaging in fact inquiries concerning considerable periods of time, a heavy burden in itself, but it would also present a significant challenge to the restraints imposed on the Court's power by its own constituent document. ${ }^{118}$ Merely

114. Tarazi wrote: "It has been argued that more would mean examining deeds of a political nature which lay outside the framework of the Court's powers. But is it possible to ignore historical developments which have direct repercussions on legal conflicts?" Id. at 26.

115. Id.

116. See W. Prosser, Law of Torts (4th ed. 1964).

117. Both Judge Tarazi and the majority noted that the United States Goverment was well aware of the effect its admission of the ex-Shah to the United States would have on the volatile situation in Iran. The majority opinion states that:

In October 1979, the Government of the United States was contemplating permitting the former Shah of Iran, who was then in Mexico, to enter the United States for medical treatment. Officials of the United States Government feared that, in the political climate prevailing in Iran, the admission of the former Shah might increase the tension already existing between the two states, and inter alia result in renewed violence against the United States Embassy in Tehran, and it was decided for this reason to request assurances from the Government of Iran that adequate protection would be provided.

U.S. Dep't of STate, Selected Docs., No. 17 at 8; Case Concerning United States Diplomatic and Consular Staff in Tehran, supra note 3.

Tarazi suggests that the causal connection between the United States' admission of the Shah and the seizure of the American Embassy is an aspect of the historical background of the case that the ICJ should have examined. U.S. Dep'T of STATE, Selected Docs., No. 17 at 27; Case Concerning United States Diplomatic and Consular Staff in Tehran, supra note 3. This portion of Tarazi's analysis would seem to indicate that he advocates a "comparative fault" type of approach.

118. The power of the Court to decide cases is limited in part by Article 38 of the Statute of the International Court of Justice in the following manner:

1. The Court, whose function is to decide in accordance with international law such disputes as are submitted to it, shall apply:

a. international conventions, whether general or particular establishing rules expressly recognized by the contesting states;

b. international custom, as evidence of a general practice accepted as law; 
taking cognizance of historical context by way of dicta in a written opinion, while undoubtedly having certain political consequences, would appear to have little legal import.

What is clear from Judge Tarazi's dissent is his belief that an examination of United States involvement in Iran prior to November 4, 1979 would go a long way towards explaining the events that occurred on that date. Such an examination, he says, would most appropriately begin with a study of the events of 1953 and the return of the Shah to the throne in Iran ${ }^{119}$ and continue with a consideration of United States involvement of Iran throughout the Shah's reign. ${ }^{120}$ Judge Tarazi emphasizes that findings of United States intervention in the internal affairs of Iran would in no way

c. the general principles of law recognized by civilized nations;

d. subject to the provisions of Article 59, judicial decisions and the teachings of the most highly qualified publicists of the various nations, as subsidiary means for the determination of rules of law.

2. This provision shall not prejudice the power of the Court to decide a case ex aequo et bono, if the parties agree thereto.

119. Judge Tarazi cited a passage from an account by Fereydoun Hoveyda, a source which he notes does not look favorably on the Islamic Revolution of Iran, in support of the proposition that the Shah's rise to power in 1953 was orchestrated by the C.I.A.:

"Some Iranian observers were skeptical, considering that foreign interests were pulling the strings: top-ranking non-British companies on the world market were pushing for a break of the contract with the AlOC [Anglo-Iranian Oil Company]. $\mathrm{Be}$ that as it may, when the nationalist uproar grew, the Iranian ruling class and various foreign powers got the wind up and turned to the Shah again. It was then that the C.I.A. vacated the idea of a coup d'etat, and in 1953 Kermit Roosevelt visited Iran to examine the possibilities and find a likely candidate."

F. Hoveyda, The Fall of the Shah, 92 (1979), cited in U.S. Dep't of State, Selected Docs., No. 17 supra note 3 , at 26.

120. As evidence of the veracity of Iranian contentions that the Shah's reign was dependent on United States involvement in Iran, Judge Tarazi cites the following passage from the memoirs of Dr. Henry Kissinger, former Secretary of State of the United States:

Under the Shah's leadership, the land bridge between Asia and Europe, so often the hinge of world history, was pro-American and pro-West beyond any challenge. Alone among the countries of the region - Israel aside - Iran made friendship with the United States the starting point of its foreign policy. That it was based on a cold-eyed assessment that a threat to Iran would most likely come from the Soviet Union, in combination with radical Arab states, is only another way of saying that the Shah's view of the realities of world politics paralleled our own. Iran's influence was always on our side, its resources reinforced ours even in some distant enterprises - in aiding South Vietnam at the time of the 1973 Paris Agreement, helping Western Europe in its supporting moderates in Africa against Soviet-Cuban encroachment. . . . In the 1973 Middle East war, for example, Iran was the only country bordering the Soviet Union not to permit the Soviets use of its air space - in contrast to several NATO allies. The Shah . . . refueled our fleets without question. He never used his control of oil to bring political pressure; he never joined any oil embargo against the West or Israel. Iran under the Shah, in short, was one of America's best, most important, and most loyal friends in the world. The least we owe him is not retrospectively to vilify the actions that eight American Presidents - including the present incumbent - gratefully welcomed.

Kissinger, The White House Years, 1262 (1979), cited in U.S. Dep't of State, Selected Docs., No. 17, supra note 3, at 26. 
justify the seizure of the United States Embassy. He suggests, however, that such United States activity should be "placed in the balance when the responsibility incurred by the Iranian Government fails to be weighed." 121

There is little dispute that the United States Government played a significant part in the development of Iranian affairs between 1953 and 1979. ${ }^{122}$ The status of such activity under international law is, however, uncertain. The intervention of nations in the internal affairs of other nations, particularly "weaker" ones, is a long-established fact of international life. Nevertheless, the United Nations has accepted the concept of total nonintervention as one of its highest principles. ${ }^{123}$

\section{The Principle Of Nonintervention IN INTERNATIONAL LAW}

The principle of nonintervention requires states to refrain from interfering in each other's affairs. ${ }^{124}$ The rule of nonintervention is derived from the principle of state sovereignty. ${ }^{125}$ Recognition by members of the international community of the right of sovereignty of their fellow members implies a duty to respect that right by refraining from intervention in those matters falling within the exclusive jurisdiction of another state. ${ }^{126}$

121. Id..

122. Roosevelt, supra note 19; see also Cottam, supra note 19.

There is some indication that the United States Government at least contemplated intevention in Iranian affairs in the period directly preceding the embassy seizure. The New York Times, on April 20, 1980, reported that United States Air Force General Robert E. Huyser went to Iran on January 3,1979 and then, following the Shah's departure, met with Iranian military leaders in an effort to develop plans for a coup in the event that the Bakhtiar government collapsed. In that article, The New York Times also noted that an official present in the embassy on the night of February 10, 1979 said that Ambassador Sullivan received a call from the White House in which a State Department official asked if it would still be possible to make the coup plans operational. Mr. Sullivan was quoted as saying that it was not. But see Ledeen \& Lewis, Carter and the Fall of the Shah: The Inside Story, Wash. Q. Sp. 1980, 3 (focusing on the period 1978-79 and the American responses to the Iranian crisis).

123. Article 2, Charter of the United Nations (principle of equal rights and self-determination of peoples); General Assembly Declaration on Non-Intervention, GAOR, Supp. (No. 14) (A/6014), at 11 ("every state has an inalienable right to choose its political, economic, social and cultural systems, without interference in any form by another state").

124. R.J. VinCENT, NoninterVENTION AND INTERnAtIONAL ORDER 20 (1974).

125. Id. at 14. A "sovereign state," according to traditional usage of that term, is one which has complete authority over persons and property within its territory and is independent of direct control by another power. A sovereign state enjoys the status of full member in the international community and is thereby accorded certain rights and privileges under customary international law. See FENWICK, supra note 53, at 125-27.

126. Id. at 20. 
The United Nations Charter does not explicitly set forth the principle of nonintervention as a rule governing the relations of member states. However, in that section of the document laying down the principles that are to guide the actions of the organization and its members, the Charter comes close to embracing such a rule. Article $2(4)^{127}$ requires all members to: "refrain in their international relations from the threat or use of force against the territorial integrity or political independence of any state, or in any other manner inconsistent with the Purposes of the United Nations." 128

The United Nations has made the implicit nonintervention rule of the Charter explicit in its practice. On December 21, 1965, the General Assembly adopted the Declaration on Inadmissibility of Intervention in Domestic Affairs of States and Protection of Their Independence and Sovereignty. ${ }^{129}$ This declaration went well beyond the charter provisions and even traditional doctrines of nonintervention. ${ }^{130}$ It disallowed economic and political methods of coercion, the interference in civil strife, and the "use of force to deprive people of their national identity." Perhaps most importantly, it stated that "all states shall respect the right of self-determination and independence of peoples and nations, to be freely exercised without any foreign pressure, and with absolute respect for human rights and fundamental freedoms." 131

Culminating an eight year effort by a Special Committee of the General Assembly to formulate seven principles of international law commanding general agreement, the Declaration on Principles of International Law Concerning Friendly Relations and Cooperation Among States in Accordance with the Charter of the United Nations was adopted on October $24,1970 .{ }^{132}$ The principle of nonintervention embodied in this declaration did not differ significantly from the 1965 Declaration on the Inadmissibility of Intervention. However, by setting forth the principle of nonintervention in this document the General Assembly increased its legal significance.

127. 59 Stat. 1031,1033 (1945).

128. Since the territorial integrity and political independence may be threatened by acts not directly involving the threat or use of force and since "territorial integrity" is a term of rather specific meaning, the U.N. Charter leaves a gray area of activity in which Article 2(4) would not apply. Hence, that Article falls short of enunciating a true rule of nonintervention. VINCENT, supra note 124 at 234.

129. G.A. Res. 2131 (xx), 20 U.N. GAOR, Supp. (No. 14) 11, U.N. Doc. A/RES/2131/

Rev. 1 (1966).

130. VINCENT, supra note 124 , at 239.

131. G.A. Res. 2131 supra note 129.

132. G.A. Res. 2625, 25 U.N. GAOR Supp. (No. 28), 121, U.N. Doc. A/8028 (1970). 
Although the General Assembly does not have express authority under the United Nations Charter to create international law, ${ }^{133}$ a Declaratory Resolution has legal import to the extent that it evidences the existence of a legal principle and defines its parameters. $^{134}$ In the case of the Declaration on Friendly Relations, the fact that its enactment and content were a product of consensus ${ }^{135}$ argued strongly in favor of its recognition as an enunciation of generally accepted principles of international law.

Despite the United Nation's efforts to establish nonintervention as a central principle of international law, prohibitions against intervention in the internal affairs of sovereign states remain vague and are generally not taken seriously. ${ }^{136}$ No multilateral convention exists upon which a State might base a claim of intervention before the International Court of Justice. It would be far too speculative to suggest that had such a document existed, had such a forum been available, the events of November 4, 1979, in Tehran would not have occurred. However, one can only assume that the onesidedness of international law added to the frustration and anger of the actors in the Iranian drama. ${ }^{137}$

The rules of international law upholding diplomatic and consular immunity are well-defined and embodied in treaties which

133. The United Nations Charter provides that:

The General Assembly . . . may make recommendations with regard to [general principles of cooperation in the maintenance of international peacel to the Members or to the Security Council or to both. U.N. CharTER, art. 11, para. 1.

134. R. Higgins, The Development of International Law Through the PolitICAL ORGANS OF THE U.N. 5 (1963); see Falk, On the Quasi-legislative Competence of the General Assembly, 60 AM. J. INT'L L. 782 (1966); but see Gross, The United Nations and the Role of Law, 19 INT'L ORg. 537 (1965).

135. The consensus method allows delegations to voice their understanding of the principle of law under discussion and only those understandings that are generally accepted are adopted by the Assembly. See Jessup, Silence Gives Consent, 3 GA. J. INT'L \& CoMP. L. 46 (1973).

136. Statements of President Gerald Ford at a press conference on September 16, 1974: Question:

Mr. President, under what international law do we have a right to attempt to destabilize the constitutionally elected government of another country. And does the Soviet Union have a similar right to try to destabilize the Government of Canada, for example, or the United States?

Mr. Ford's response:

I'm not going to pass judgment on whether it's permitted or authorized under international law. It's a recognized fact that historically as well as presently, such actions are taken in the best interests of the countries involved.

Transcript of News Conference, New York Times, Sept. 17, 1974, at 22, reprinted in Comment, President Gerald Ford, C.I.A. Covert Operations, and the Status of International Law, 69 AM. J. INT'L L. 354 (1975).

137. See generally Falk, supra note 9, at 411. 
can be interpreted and applied by the International Court of Justice to the facts before it. There are no such rules governing the interference by one State in the internal affairs of another, no matter how blatant or oppressive that interference may be.

The United Nations has taken the first step; it has established the principle of nonintervention. Yet, it has failed to give that principle the clarity it needs to be of aid to weaker nations struggling against the pressure of more powerful States for whom interventionist policies are both possible and profitable.

\section{CONClusion}

Perhaps out of the tragedy of the Embassy seizure in Iran will come a greater understanding of the causes of international terrorism and a heightened impetus to address those causes and seek their eradication on an international level. The international community must, if further tragedies of this nature are to be avoided, find a way to bridge the schism that has divided its members on the issue of international terorism in the past, ${ }^{138}$ and take decisive steps to address the underlying causes of terrorist activity in order that future incidents can be prevented.

The United Nations should heed the recommendations of the Ad Hoc Committee on International Terrorism ${ }^{139}$ and undertake an intensive study of the causes of terrorism, including the intervention of foreign states in the internal affairs of nations. Having explored that particular issue, the United Nations should take steps to clarify the status of interventionary behavior under international law ${ }^{140}$ and to adopt a multilateral convention prohibiting specific conduct by states' parties. ${ }^{141}$ While such measures alone will not

138. See notes $36-37$ and accompanying text.

139. See notes 43-44 and accompanying text.

140. At least one commentator is skeptical of such a "global approach" to solving the problem of intervention, arguing that diplomacy is inevitably interventionary. He suggests, instead, that "citizens through voluntary associations should organize to regulate the behavior of governments." Falk, supra note 9, at 412-13.

141. The drafting of a Convention on Non-Intervention would no doubt encounter substantial difficulty in light of the importance of the issue to member states. By restricting themselves to the prohibition of narrowly-defined types of behavior, the drafters might simplify their task and meet with greater success, as did the drafters of the United Nations Convention Against the Taking of Hostages. See notes 48-55, and accompanying text.

The International Law Commission is now in the process of drafting articles as relating to the responsibility of States for internationally wrongful acts as part of its ongoing attempt to codify the principles of international law governing State responsibility. These draft articles will be used as the bases for the conclusion of a convention if the U.N. General Assembly so decides. Draft Article 19 provides that an international crime may result from a "serious 
California Western International Law Journal, Vol. 11, No. 3 [1981], Art. 14 568

eradicate the problem of international terrorism, they would constitute a great stride in that direction.

breach of an international obligation of essential importance for safeguarding the right of self-determination of peoples, such as that prohibiting the establishment or maintenance by force of colonial domination." U.N. Doc. A/35/10 (1980). The language of this provision would seem to include acts of political and economic intervention such as those complained of by the government of Iran in the Iranian Hostage Case. 